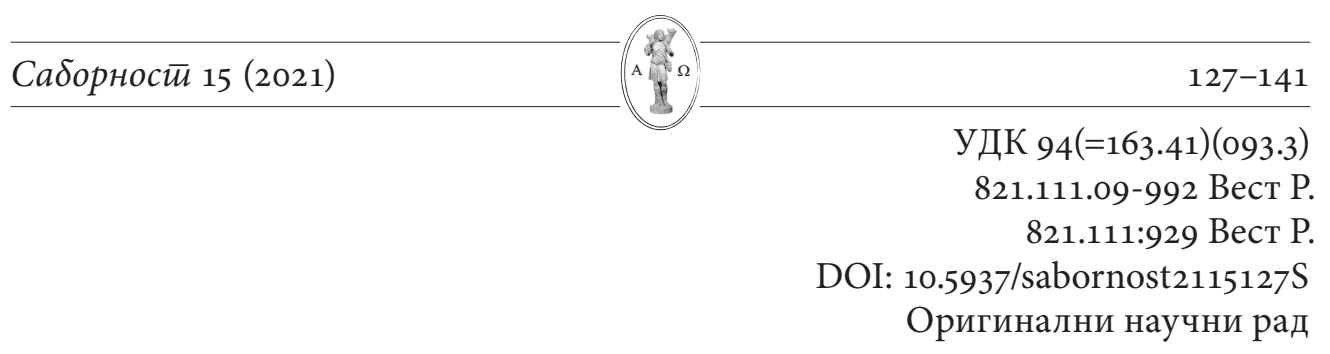

\author{
Ивана Стојановић Шешлак \\ Универзитет у Београду, Филолошки факултет, Београд (докторанд)
}

Културна баштина на Косову очима Ребеке Вест

\begin{abstract}
: Великом делу наше јавности познато је име британско-ирске списатељице Ребеке Вест. Домаћа публицистика обилује текстовима о поменутој ауторки услед њеног изразито позитивног писања о Србима и српској култури. У путопису Црно јаїғе и сиви соко, Вестова исказује велико дивљење према нашој културној башти-

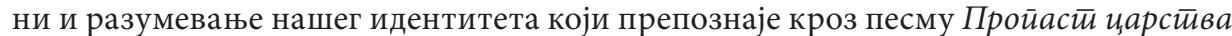
срйскоїа. Приликом боравка у Македонији, упознаје владику Николаја, кога сматра једном од најизванреднијих личности које је срела. Кроз претходно поменуто, ауторка провлачи поређење између Косовског боја из 1389. и Енглеске 1939. У овом раду, покушаћемо да представимо њен доживљај манастира на Косову, указујући на чињеницу да је себе сматрала другачијом у односу на друге западне ауторе који су, као и она, писали о Балкану.
\end{abstract}

Key words: Ребека Вест, културна баштина на Косову, Грачаница, Дечани.

$\mathrm{B}^{\mathrm{e}}$ еликом делу наше јавности познато је име британско-ирске списатељице Ребеке Вест (Rebecca West). Записима у виду путописа, о јужнословенским крајевима које обилази крајем тридесетих година двадесетог века, оставила је велики печат у путописној литератури. Отуда, то је остварење оценом многих аутора попримило епитет генијалног. Домаћа публицистика обилује текстовима о поменутој ауторки због њеног изразито позитивног писања о Србима и српској култури. Неки аутори говоре о исказаној превеликој симпатији према српском народу, јер остаје верна тој наклоности до краја живота. У књизи Земъа чуgа у изломленом оїлеgалу (1994), Игњачевић наводи њену „свесрдну симпатију (повремено и опсесију)“ према позитивним карактеристикама српског народа и менталитета'. Њена опчињеност Словенима, које види као изразито интелектуалан народ, само је почетак и делић мозаика који је склопила боравећи на нашим просторима. Наиме, на многим страницама путописа Вестова исказује дивљење према

\footnotetext{
ivanaseslak@gmail.com

1 Игњачевић, 1994, стр. 63.
} 
нашој културној баштини, истичући се међу другим ауторима разумева-

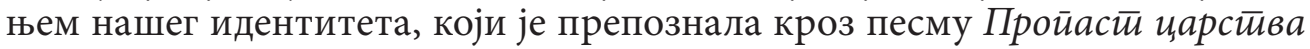
срйскоїа. Разумевање српске културе кроз епску поезију можда је најбоље описао Емир Кустурица. У „Слову о академику Милораду Екмечићу“, предговору књиге Печай Милораgа Екмечића (2018), Кустурица за њу вели како је „једна од ријетких западних интелектуалаца која је разумјела нашу позицију и са симпатијама писала о Србима, примјетила је како ниједан други народ није историјско памћење створио научивши толико дугих строфа напамет“2. Познавање епских песама не значи да није била упозната са историјским збивањима на Балкану, самим тим и онима у Jyгославији. Сам податак да је о тој земљи научила подоста, према мишљењу Весне Голдсворти, јесте за дивљење. У књизи Измииљаюе Руритианијез, Голдсвортијева каже: „[3]аслужује још веће дивљење ако се има у виду да је своју књигу написала у веома кратком року, захваљујући томе што се претходно случајно обрела у делу света који је за њу био потпуно нов“4. У Преgїовору свог превода путописа Црно јаїне и сиви соко (200о), под насловом „Југославија Ребеке Вест“, Кољевић за Вестову наводи како је, пре свог другог боравка у Југославији „прочитала о Балкану све књиге до којих је могла доћи“". Интересантно је напоменути да о Словенима, које је нарочито заволела, није знала готово ништа. То је био додатни подстицај за њу да се ода истраживању, те је тачно тврђење да је „љубав за једну земљу и њене људе“ изазвала „жеђ за све већим знањем““. Идеја водиља приликом писања дуге и компликоване књиге, како ју је назвала, била је у жељи да прикаже прошлост и садашњост:

„[Ч]инило [joj се] да је писање ове страшне књиге - хронике бола, насиља и крвопролића у којој су се народи тако дуго окретали једни против других - неиздржив задатак; а можда је оно најстрашније што сам је, да бих остварила свој наум и показала како се садашњост зачиње у прошлости, морала завршити док око мене бесни зло једнако оном које сам описивала. Сада читава Европа пати као Словени, под непријатељем кога је теже победити него Турке“ (Vest, 2017, стр. 799).

Вестова пише како би, док је трајало бомбардовање, молила Бога да јој „подари храброст коју имају Срби“: „[3]нала сам да немам права да то тражим јер су нам Словени браћа, и да је грех који смо нашом неспособношћу починили према њима неопростив“ (Vest, 2017, стр. 799). Претходним редовима указује на своје неслагање са политиком попуштања која је вођена у

2 Кустурица, 2018, стр. 7.

3 Књига је први пут објављена на енглеском језику 1998. године, под насловом Inventing Ruritania: The Imperislism of the Imagination. Превод који овде користимо објављен је 2005. године.

4 Goldsvorti, 2005, стр. 211.

5 Koljević, 2000, стр. 5.

6 Koljević, 2000, стр. 6. 
годинама пред избијање Другог светског рата. Говорећи о ситуацији у којој се свет нашао, и њена Енглеска, промишљајући каква ће их судбина даље задесити, закључује да „ни Чеси ни Пољаци не би патили да ми нисмо били тако слаби да смо у нашем необјашњивом лудилу пузили пред сопственим џелатима" (Vest, 2017, стр. 799). Сличним поређењима и тврдњама Ребека Вест показује да се јасно разликује од других аутора који су као и она писали о Балкану. У њеним редовима лако се може препознати да је од оних који сматрају „да осим што треба понешто научити о Балкану, има се шта научити и og Балкана“". Због отворенијег става према византијском наслеђу које је пронашла на Балкану, могла је боље да разуме балканске народе, њихову патњу и њихову културу. Према Голдсвортијевој, у „најрефлексивније странице Црної јайғеейа и сивої сокола спадају оне на којима Ребека Вест описује свој сусрет са духовним наслеђем Византије“8. Према Голсвортијевој, Вестова је поверовала да је Србима који су „дуго били бедем који је штитио Европу од ислама, подарено посебно откровење хришћанства“". Косово поље обилази заједно са Константином, у стварности песником Станиславом Винавером. У сусрету са Косовом пољем, Вестова бележи како је непомичност Косова „И нас учинила непомичним“ (Vest, 2017, стр. 6оo). Према њеном специфичном виђењу односа између неког места и нас самих, „[в]ише него иједно друго историјско место Косово изазива такву страшну потиштеност [...] [О]но је препуно мртвих који нису умрли само телом, јер је с њима у гроб бачена и њихова цивилизација“ (Vest, 2017, 601). Према мишљењу многих аутора, Винавер је имао велики утицај на Вестову. Пошто су срели двојицу дечака у близини сиротишта, Константин их је упитао зашто је баш на том месту подигнуто сиротиште. Вестова бива задивљена дечијим знањем, утолико што „одговорише нежном и детињастом верзијом званичне приче“, будући да су дечаци знали све о славном Царству, његовом поразу, петовековном ропству, али и о Југославији (в. Vest, 2017, стр. 603-604). На Константиново питање знају ли песму коју је испевао народ о Видовдану, Вестова примећује да дечаци док рецитују изгледају „узвишено и побожно“, али са „оним неисцрпним, бујним и речитим памћењем словенске деце“ (Vest, 2017, стр. 604). Свесна да се то може назвати национализмом, ауторка још једном показује различитост у односу на друге ауторе са Запада. Наводи како би интелектуалци њених година такав вид национализма прогласили маном, па и „узроком свих светских невоља“, али не и она. Увиђа да „свако људско биће мора бити подстицано да у пуној мери развија своју свест" (Vest, 2017, стр. 604). Сусрет са Косовом и размишљањем о историји учиниће да запише:

\footnotetext{
7 Goldsvorti, 2005, стр. 217.

8 Исто.

9 Исто.
} 


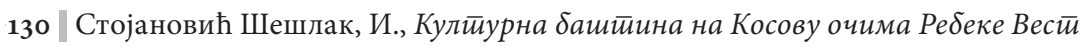

„Ако би неки див узео Косово у своју десну руку, а нас, цркву, сеоско имање и гроб у леву, његова десна рука пала би под тежином терета, а у левој би му се чинило да не држи ништа осим мало прашине [...] Радост која се осећа због Косова не може послужити као права противтежа огромној патњи која избија из Косова“ (Vest, 2017, стр. 605)

Вестова показује како има разумевања за људску патњу, коју је највећим делом видела на Косову. Док описује становништво те области увиђа да су њихове куће оронуле, одећа прљава, док „зуре у странце очима у којима нема ничег осим летаргичног страха који је у нескладу са садашњицом“ (Vest, 2017, стр. 605). Наредним редовима, исказује генијалност разумевањем тих жена, што не бисмо очекивали од западних аутора. Има разумевања за те жене које изгледају „друкчије него што је њиховом соју писано“ (Vest, 2017 , стр. 606), јер је свесна страдања и готово осакаћености популације. Из тих разлога, констатује како оне „нису прави узорак словенске популације која је овде живела у време Косовске битке“. Многе породице пале су на Косову а велики број се иселио у Аустроугарску (в. Vest, 2017, стр. 606). Манастир Грачаница на Вестову оставља најјачи утисак. Приликом посете том манастиру срећу архитекту из Београда, који познаје Константина. Постојала је потреба за изградњом новог манастирског конака:

„Сваке године за Видовдан, на годишњицу Косовске битке, овамо пристижу десетине хиљада ходочасника. За све њих никако није било места. Румени од тога што је празник и несрећни од размишљања о националној трагедији, они ће и даље спавати на њивама испошћеним летњом врелином, као што су одувек и чинили“ (Vest, 2017, стр. 608).

Поменути архитекта указује на срећу која му се пружила да ради у манастиру, јер „у Београду човек заборавља шта је његов народ, какви смо стварно“ (Vest, 2017, стр. 6o8). Како би их уверио у своје мишљење да Срби нису били варвари, док су ишли према цркви, архитекта говори о изузетности тог споменика културе:

„Погледајте је. Ништа на њој није случајно. Њу није градила једноставност, већ крајње интелектуална комплексност. Пуна је изузетних решења која тешко могу разумети они који нису архитекте. Куле које држе куполе померене су у односу на своју средишњу осу. То је учинио неко ко је тачно знао да се тиме постиже ефекат елеганције и лакоће, а да се тако нешто постигне потребно је много теоријског и практичног знања. О, шта је све овај градитељ 3нао!“ (Vest, 2017, стр. 608-609).

Наведене речи нису само речи хвале. Исказују високи степен дивљења према градитељу чије је умеће било скоро савршено. Чињеница да се на том терену сусрећу подземне воде није представљала проблем. Градитељ се није узбуђивао, „био је сигуран у своје знање“ (Vest, 2017, стр. 6о9). Додајући како грађевина и након шест стотина година и даље стоји иста каква је била говори о величанствености оних који су заслужни за њено постојање. Међутим, унутрашњост Грачанице може рећи много више, тачније, „рећи 
ће вам све о људима који су је саградили“ (Vest, 2017, стр. 609). Велики утисак на Вестову оставља светлост која се из купола спуштала падајући доле и попримајући одсјај фресака. Ауторка описује и фреску на којој је приказан ктитор манастира, краљ Милутин. Краљ је приказан као висок човек, усправног држања, „обучен у одору карактеристичну за српске краљеве, која очито потиче из Византије: то је крута туника од богатог материјала посута драгим камењем“ (Vest, 2017, стр. 609). Њена намера јесте да укаже на чињеницу да је краљ приказан као вољени Божји изасланик, и то не зато што је изузетан, него зато што је друштво сигурно у то. Он ће „учинити све да се понаша као вољени Божји изасланик, пошто је то оно што краљ треба да чини“ (Vest, 2017, стр. 609). Вестова описује и фреску на којој је представљена Симонида: „Поред Милутина стоји, једнако величанствена, његова жена Симонида, ћерка византијског цара Андроника II“ (Vest, 2017, стр. 609). Интересантна је прича о догађајима који се везују за рођење Симониде. Ауторка преноси читаоцима колико је велики значај Симонида имала за свога оца. Била му је врло драга, што је и очекивано, нарочито што „се родила после неколико кћери које нису остале у животу“ (Vest, 2017, стр. 614). Зато „дванаест једнаких свећа запаљено је пред иконама дванаесторице апостола, и док су оне гореле читане су молитве за дете; девојчица је стављена под заштиту оног апостола чија је свећа најдуже горела“(Vest, 2017, стр. 614). Тако је и добила име Симонида. Своју вештину у излагању ауторка показује износећи многе друге легенде које се везују за то време. Познато је да је Милутин протерао свога сина Стефана у Константинопољ, заједно са његовом децом, Душаном и Душицом. Вестова пише да је то учинио по налогу византијских саветника. Излаже да је обичај ослепљивања који се тада користио као казна пореклом византијски. Пошто је само делимично ослепљен Стефану се по легенди, коју такође бележи, јавио у сну Свети Никола рекавши: „Не плаши се, твој вид је у мојим рукама“" (Vest, 2017, стр. 616). На крају, за целу причу коју је испричала вели како би читалац са Запада могао рећи да је то прича о варварству која „показује да на Косову није нестало ништа за чим вреди жалити“ (Vest, 2017, стр. 617). На том месту, ауторка изнова показује своју различитост у односу на друге западне ауторе. Према њој, цела прича уткана је у Грачаницу, у „огромно богатство њених боја и у њену снажну и савршену форму“ (Vest, 2017, стр. 617). Милутин је за њу био прави краљ, за кога сматра да је своју земљу окренуо сунцу. Фреска на којој је приказана Богородица како пада у сан, посебно је окупирала њену пажњу. То је тема коју су Византинци често представљали. Лепота фреске навела је ауторку да напише како „[д] анас не постоји ни један једини човек који би, размишљајући о тој идеји, могао да је прикаже на тај начин. [...] Опуштеним али сигурним потезом приказано је чудо смрти“ (Vest, 2017, стр. 621). Дата фреска је према њеном мишљењу најчистије сликарско умеће. С једне стране, у њу је уткана туга, коју ауторка разуме као искрену тугу коју дете осећа после смрти мајке. С 


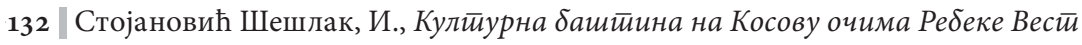

друге стране, увиђа се и велико усхићење, које проистиче из чињенице да Син може чинити чуда, а тиме и поништити сваку смрт (в. Vest, 2017, стр. 622). Радомир Станић ${ }^{10}$ за краља Милутина пише како је умео „да одабере најдаровитије византијске мајсторе, да их окупи око себе и да им повери осликавање својих најзначајнијих задужбина“". Михаило и Евтихије најистакнутији су сликари поменуте епохе, премда су у осликавању учествовали „и помоћници, међу којима је било мајстора српског порекла“" Према мишљењу Вестове, уметници „су овде имали оно највеће богатство које као уметници могу стећи: нису штедели свој дар јер су стварали за публику која је имала богату моћ опажања“ (Vest, 2017, стр. 622). Сусрет са Приштином, некадашњом престоницом српских краљева, на истоветан је начин интересантна прича. Ауторка читаоца води кроз многе историјске догађаје, анализирајући њихове последице. Очигледно је да је Приштина изгубила славу коју је некад поседовала. У ресторану који су одабрали на менију је било само једно јело, а на столњаку мрља. Константин претпоставља како ће Вестова, пошто се врати у своју земљу, презирати Србе и „причати како смо као свиње, а притом ћете заборавити да нисмо имали предности као ви у вашој земљи, јер ви сте увек били богати“ (Vest, 2017, стр. 624). Међутим, ауторка изнова има разумевања за људе са простора старе Србије. Како истиче, они једноставно „нису чули за обичај да столњаци треба да буду чисти“ (Vest, 2017, стр. 624). Ма каква Приштина била, чиста, сиромашна или прљава, муж Ребеке Вест примећује како се људи ту ипак необично добро носе и нису утучени. Константин додаје да је стара Србија била најнеразвијенија област у оквиру Турске, с тим што је некада било и много горе (в. Vest, 2017, стр. 624). Покушавајући да објасни прошлост, Вестова бележи:

„Да није било Турака, византијска цивилизација преселила би се овде и процветала још једном у Српском царству, као што је велики део наше европске цивилизације прешао у Америку, где живи на универзитетима, у уметничким галеријама, концертним дворанама и лабораторијама, већим од оних које ми можемо себи да допустимо“ (Vest, 2017, стр. 625)

На наредним страницама наилазимо на сличне примере у којима ауторка исказује став о различитим историјским догађајима, личностима, могућим шансама и пропуштеним приликама. Један од тих примера је и Стефан Душан. Могао је „спасити Европу од Турака, или их барем држати на одстојању, дајући тако Европи довољно времена да се наоружа“ (Vest,

10 Радомир Станић, Кулӣурна ризнииа Србије, о уметничкој вредности фресака манастира

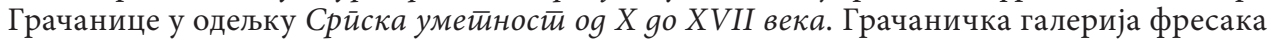
има високу уметничку вредност, где се „препознају завршни облици прве фазе развоја српског сликарства XIV в., сврстава се међу најзначајније и највеће ризнице сликарског стваралаштва овог столећа“ (Станић, 2002, стр. 136).

11 Станић, 2002, стр. 134.

12 Исто. 
2017, стр. 640). Последице би биле много боље по Европу. Мађарска би била поштеђена, а Беч би избегао чувену опсаду 1683. године. Уједно, вероватно не би било ни Аустроугарске, која је „најстрашнија од свих страхота“ (Vest, 2017, стр. 640). Из претходно изнетог, може се без двојбе закључити какав је поглед имала на стварање Монархије. Разумевала ју је као тамницу народа. Приликом посете Пећкој патријаршији, ауторки се чинило да се налазе „на најспокојнијем месту на свету“ [...] Црква је представља „спој три мале цркве које стоје једна уз другу, свака са куполом и заобљеном апсидом“ (Vest, 2017, стр. 688). Прву цркву је подигао патријарх Арсеније, јер је Жича, седиште архиепископије била изложена, не само најездама Татара него и угрожена од Мађара. Ауторка сматра да је требало наћи „боље склониште ка југу“ (Vest, 2017, стр. 689). Црква јесте била центар духовног живота Срба, међутим, губи независност са доласком Турака. Са великом сеобом Срба, патријаршија је пресељена у Карловце. За манастир Дечане Вестова вели како представљају „прави драгуљ“:

„На улазу у удолину стајао је бели, правоугаони манастир. Био је већи од иједног који смо већ видели, чак и са даљине из које смо га посматрали одмах се видело да је реткост, прави драгуљ [...] изграђен од блокова белог, сивог и ружичастог мермера који се стапају у јединствени благи, бледи сјај“ (Vest, 2017, стр. 698).

Иако монументални, Дечани нису толико задивили Вестову као што је то учинила Грачаница. Ауторка признаје како је њено око навикнуто на византијска мерила. Отуда јој се не допада што је градитељ Дечана био католик, што схвата као „додир са западном црквом“ (Vest, 2017, стр. 699). Наиме, главни мајстор био је фра Вита, пореклом из Котора. Константин, као страствени обожавалац историје и историјских споменика, повео их је до моштију Светог Краља. Вестова је приликом обиласка морала да види „џиновску свећу коју је манастиру дала удовица цара Лазара после његове погибије на Косову, уз налог да се упали онда када Косово буде освећено, што је 1913. године учинио краљ Петар Карађорђевић“ (Vest, 2017, стр. 701$702)^{13}$. Њену нарочиту пажњу привукао је и лустер, који је „од оне прекрасне врсте“, који се могу видети у Светој Софији или на Светој Гори. Описује и један, за њу необичан догађај, када једна муслиманска породица долази у манастир. Били су то Албанци, два мушкарца, три жене, беба и два дечака. Пошто им је свештеник нешто рекао, мушкарци су скинули своје капе а жене уклониле фереџе. Константин јој је објаснио да је петак, свети дан код муслимана: „Доводе своје болеснике да их излече наши, хришћански свеци. Гледајте шта раде“ (Vest, 2017, стр. 702-703). Свештеник им је појаснио како су обичај смислили сами Албанци. Очигледно је да Вестова јасно показује дистанцирање од других аутора са Запада који, како више пута

13 Кнегиња Милица манастир Дечане посетила је са својим синовима 1397. године, када је манастир даривала и вратила отета имања манастиру (в. 124. стр. Светииюе Косова и Мeйохије, Слободан Милеуснић). 


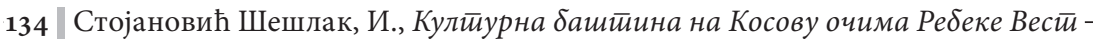

примећује, немају довољно разумевања како за обичан народ који опстаје на тим просторима, тако ни за њихову културу. Сматра задивљујућим то што људи које срећу не изгледају утучено, упркос тешким условима живота. Напротив, задовољни су оним што имају. Насупрот томе, иако и сама потиче из Енглеске, за своје сународнике вели:

„Енглези су се обично понашали врло тупаво, задојени империјалистичком идејом да је имати добро, и стога склони да погрешно закључе да они који немају нису добри. Енглески путник из XIX века био је склон да неповољно мисли о хришћанским поданицима Османске империје јер су били прљави, неписмени, похлепни (што сиромаси, за живо чудо, често бивају), сервилни, негостопримљиви и неваспитани (што заплашени људи, за живо чудо, често бивају)“ (Vest, 2017, стр. 778).

Вестова се не слаже са империјалистичким схватањима према којима поједини народи не заслужују слободу, већ им је потребно туторство. Турцима су се често приписивали епитети изузетних, оцењивани су као „култивисани, великодушни, достојанствени, гостољубиви и веома учтиви“ (Vest, 2017, стр. 778). Таква слика о Турцима нестаје са опадањем њихове моћи. Међутим, ту су присутне и Аустријска и Руска империја. За Аустроугарску и њену династију сматра да се према другим народима опходила врло лоше. Отуда, прихватање Мађара и стварање Двојне монархије плод је тога што су „мрзели Словене и нису се либили прогона Хрвата и Срба“ (Vest, 2017, стр. 780). Данас би се такве тврдње могле оценити непримереним. Међутим, гледано из угла Ребеке Вест, која је величала слободу, а одбацивала империјализам, дате тврдње не делују изненађујуће. Након Првог светског рата, слобода је малим народима „дала огроман полет“, док се притом „[у] историји [...] досад није десило ништа величанственије од ослобођења ових народа који током векова тлачења нису заборавили своју душу“ (Vest, 2017, стр. 781). Њено узвишено схватање слободе, са којим би се већина аутора данашњице сложила, уско је везано и са појмом национализма. Национализам види као „решеност једног народа да негује своју сопствену душу, да следи обичаје које су му завештали преци, да развија своју традицију“ (Vest, 2017, стр. 782). Српском народу остало је завештање

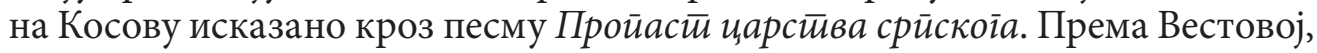
та песма „слави жељу за смрћу; али њено скривено значење бије животом“ (Vest, 2017, стр. 812). Слобода је исказана очувањем традиције, чувањем своје душе, те је решеност за царство небеско смислен и разумљив избор. Као што казују стихови песме „земаљско је за малена царство, а небеско увек и довека“. Према Душану Бандићу, косовски мит исказан кроз ту песму, представља „праву апотеозу смрти“"14. Дилема испред које се налази кнез Лазар јесте дилема између живота и смрти, између царства земаљског и Царства Небеског. Бирањем смрти Лазар заправо бира живот. Питање које стихови песме постављају јесте коме се приволети царству. Како

14 Бандић, 2008, стр. 228. 
је „земаљско за малена царство“, а „небеско увек и довјека“ јасно је какву одлуку доноси кнез Лазар. Бандић сматра да стихови поседују хришћански карактер, јер су „били инспирисани црквеном литературом“, као и култом кнеза Лазара ${ }^{15}$ : „Лазар је ту приказан као хришћански херој који се бори и који умире за веру [...] Пред нама је без сумње типично финале 'житија' једног хришћанског мученика" ${ }^{\text {"16. }}$. Александар Павловић ${ }^{17}$, који разматра настанак и развој Косовског мита, увиђа да је мит заснован на више различитих традиција. У својим разматрањима, он издваја православну: „Прву чини монашка или православна традиција, хришћанска по свом духу, која настаје непосредно после самог боја, а слави Лазара као мученика који се жртвује за Господа и хришћанску веру“'8. Павловић сматра да косовска епика заузима посебно место у усменој традицији Срба, коју је успоставио Вук Караџић заједно са својим следбеницима. Из такве традиције, која је славила пораз, формирао се идентитет српског народа. Према том аутору, косовска епика „дуго је уживала похвалу и међу страним ауторима, коју су је листом проглашавали за један од великих светских примера народне епске традиције ${ }^{{ }_{19}}$. Међутим, исти аутор разматра и друге $^{20}$, који су се критички односили према постојећем миту, те „изразито критички пишу о самом Косовском миту и одричу Србима ове - и било које друге - квалитете и красоте које им приписују 'глорификатори'“21. Расправљајући о национализму и књижевности, Жунић у књизи Нацио-

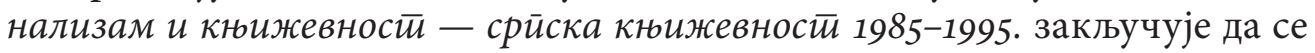
народ „не може одрећи сопственог идентитета, нити би тако нешто било пожељно“" ${ }^{\text {“2 }}$ Међутим, сматра да је потребно радити на „очувању битних епских момената идентитета тамо где они данас уистину припадају - у народној књижевности, фолклору, обичајности“ и истовремено обесхрабривати различите покушаје да се они из једне културне сфере „преводе у идеолошки дискурс ради политичког манипулисања" ${ }_{23}$. Иако циљ овог рада није да се прецизније одреди место оних који су били присталице или критичари Косовског мита, важно је истаћи да Ребека Вест, као страна ауторка, има изразито афирмативно виђење тзв. Косовског мита. Проналазећи паралелу између Косова и Енглеске, примећује како је разлика

\footnotetext{
15 Бандић, 2008, стр. 229.

16 Исто.

17 Pavlović, 2019.

18 Pavlović, 2019, стр. 39.

19 Pavlović, 2019, стр. 35.

20 Више о присталицама и критичарима Косовског мита у одељку „Увод: србољупци и србомрсци - слављенички и проказујућ приступ косовској традицији“ (Pavlović, 2019, стр. 34-42).

${ }^{21}$ Pavlović, 2019, стр. 36.

22 Žunić, 2002, стр. 92.

${ }_{23}$ Žunić, 2002, стр. 93.
} 


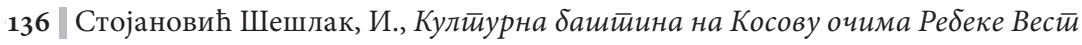

„између Косова 1389. и Енглеске 1939. лежала је у времену и месту, не и у догађајима; они су личили једни на друге до најситнијих детаља [...] И у једном и у другом постојао је тај чудновати елемент вољног подавања новој претњи технолошке природе“ (Vest, 2017, стр. 794). Оно што је некада представљала коњица коју су Турци користили у поробљавању балканских народа, сада представљају Немци који прете авијацијом. Услед тога, сличност између Енглеза и Срба постаје неизбежна. Поново је полетео сиви соко из Јерусалима и „Енглезима је предстојало оно што беше задесило словенске хришћане; гркљан ће им бити пререзан као да су црно јагње у рукама паганског свештеника“ (Vest, 2017, стр. 796). Како истиче Анђелија Миладиновић у чланку „Косовски мит у путописима о Краљевини Југославији“ (2019), Ребека Вест није усамљена међу страним ауторима који се изразито потврдно односе према Косовском миту: „[3]а мноштво путописаца међуратног периода, Косово је било кључан део њиховог описа, круна њиховог путовања, откриће тајне Југославије. Феномен слављења пораза, храброст, пркос, жртва и несебичност су појмови које користе док са највећим поштовањем пишу о Косову“24. Косовски мит, иако изворно заснован на српској традицији, мења се и постаје заједничка идеја за идеологију југословенства. Више хрватских идеолога прихвата Косовски мит и даље га обрађује. Најпознатији пример коришћења тог мита у сврху идеје југословенства јесте Иван Мештровић, који је осмислио изглед будућег Видовданског храма. Такав храм, дуг преко сто метара са фигурама косовских јунака „би представљао стуб југословенства као својеврсне државне или секуларне религије “25. На том примеру може се видети како се митови могу мењати и служити духу времена. Међутим, суштина мита остаје иста, јер слави истовремено и пораз и победу. Главна идеја народног певача била је да објасни пораз, јер пораз на Косову пољу значио је и пропаст српске државе. На тај начин, судбина кнеза Лазара врста је метафоре помоћу које се представљала историјска судбина Срба. Наиме, Лазар се свесно жртвује да би очувао сачувао своју душу и душу свог народа:

„[П]редање о судбини српског кнеза Лазара само је једна поетска слика помоћу које је српски народ представио сопствену историју [...] Срби су, дакле, представили себе као народ који је морао 'умирати' да би могао да 'живи' [...] Таква слика сопствене судбине можда је наивна али - у оном најопштијем смислу - није нетачна. Она одржава историју једног малог народа, који се нашао на историјској ветрометини Балкана и који је био принуђен да се бори за опстанак против много бројнијих и много моћнијих народа“"

Разматрајући место које Срби заузимају у светској историји, Владика Николај је у књизи Душа Србије (2003) подсећао како српски народ не

\footnotetext{
${ }^{24}$ Миладиновић, 2019, стр. 237.

25 Pavlović, 2019, стр. 41.

${ }^{26}$ Бандић, 2008, стр. 237-238.
} 
памти „нашу Карпатску историју [...] коју смо делили са Русима и осталом словенском браћом“, али зато познајемо балканску историју. Према његовом мишљењу, косовска битка је „приказана као сукоб неба и земље, бесмртног и смртног, пролазног и непролазног“, док је, српски народ кроз епске песме нашао разлоге за, „ову страховиту битку и њен исход“"27. Приликом боравка у Македонији у Охриду, Вестова среће владику Николаја, за кога бележи да јој се „учинио као најизузетнији човек на свету“ (Vest, 2017, стр. 517). Забележиће како је поседовао „власт над средствима која су правила чаролију, а његова изузетна лепота, од оне лавље врсте, и глас попут тихе грмљавине, истовремено и величанствен и грлен, показивали су да може разговарати са боговима, људима и животињама“ (Vest, 2017, стр. 517). Поглед попут његовог никада није видела „био је то поглед бога који наређује сунцу да засени месец“ (Vest, 2017, стр. 519). Сусрет са владиком Николајем оставио је огроман утисак на Вестову. Ако бисмо се вратили схватању односа Царства небеског и царства земаљског, као основе идентитета српског народа, неупитно је да је владика српски завет тумачио „пре свега, у духу наслеђа Светог Саве и Светог кнеза Лазара“"28. Питање је, међутим, колико је владикино тумачење српске историје (али и европске) утицало на ауторку путописа. Према Ковићу, опредељење за Царство небеско јесте опредељење за „царство вечних вредности, правде, љубави,

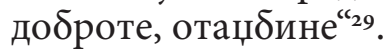

Ребека Вест је као путописац, имала идеју да пише о малој нацији која се бори како би очувала своју самосталност насупрот великим освајачима. Таква идеја идеално се уклопила у Косовски мит ${ }^{30}$, који у својој суштини то и представља. Мали народ свесно се жртвује како би сачувао своју душу и идентитет. Током таквих историјских збивања, у којима једна заједница или мали народи бивају угрожени, „у ситуацији изненадног напада од стране много надмоћнијег непријатеља“, долази до тзв. сажимања историје „у серију слика и образаца који доводе до снажне митске идентификације “31. Са издвајањем одређених примера из различитих народних казивања, и то оних који су по правилу „најсветлији примери храбрости“, долази до формирања мита. ${ }^{32}$

\footnotetext{
27 Владика Николај, 2003, стр. 22-23.

28 Ковић, 2020, стр. 41.

29 Ковић, 2020, стр. 42.

30 Милош Ковић, предања о Косовској бици која су после толико година надахњивала генерације у, како каже „доношењу судбоносних одлука“ називана су Косовским митом, заветом, предањем, култом, опредељењем, легендом, али и Видовданском етиком, Видовданском идејом и култом.

"Косовски завет и национални идентитет Срба“. https:/stanjestvari.com/2018/o2/12/kovic-kosovski-zavet-nacionalni-identitet/.

${ }_{31}$ Matić, 1993, стр. 675-676.

${ }^{32}$ Исто.
} 


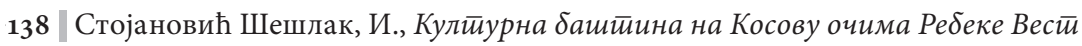

Ауторка је дубоким разумевањем словенских народа хтела да пружи сопствени суд о стању европске цивилизације. Изражавајући неповерење према империјама и сматрајући да је њихов век трајања ограничен, свесрдно се залаже за право малих народа који ступају на историјску сцену. То је период када су, након Првог светског рата, нестали Османско царство и Хабсбуршка Монархија. На њиховим развалинама, настале су нове националне државе. Истовремено, то је и период када се увиђа да је на помолу нови сукоб и да је постојећи поредак уздрман. Не треба заборавити да је убиство краља Александра у Марсеју пресудан догађај који је утицао на Вестову да се заинтересује за јужнословенске народе. Идеја о томе како прошлошћу објаснити садашњост, као и питања одговорности империја за судбине малих народа провлаче се кроз ауторкино дело. То је и својеврстан позив другима да се запитају о многим историјским догађајима и одговорностима великих за патње малих народа:

„Најопштија од ових идеја јесте скепса према великим империјама, од сопствене, британске, преко римске, турске, до хабсбуршке [...] У том контексту она се залаже за веће разумевање и наклоност Запада према нама, за превладавање клишетираних представа о балканским - и уопште малим - народима, у којима првенствено види наду за добробит Европе “"з3.

Могло би се рећи да је Вестова разумевањем балканских народа иступила како би указала на потребу да Запад подробније разуме југоисточни део Европе који му географски припада (а чини се тако далек). Истовремено, превагнула је и жеља ка дубљем разумевању себе саме. Осећала је како ју је то путовање променило. Представљало је пут који је морала да пређе, лавиринт који је требало да разреши:

„Повратак ми је донео осамљивање. Ништа ме у животу није тако погодило као ово путовање кроз Југославију. [...] Али ово путовање погодило ме је и зато што сам захваљујући њему пронашла ону вунену нит која ће ме извести из лавиринта у коме сам, како сам са запрепашћењем открила, била зазидана. Може бити да ћу се, када пратећи ту нит стигнем до њеног краја, наћи пред закључаном капијом, и да ћу схватити да је тај лавиринт оно једино што ми је на овој планети додељено. Али, ако ништа друго, сада сам знала његове кривине и вијугања, знала сам и који његов ходник води у коју засвођену одају, док ми, пре мог одласка у Југославију, ништа није могло разоткрити те мистерије“ (Vest, 2017, стр. 773).

Вођена жељом да разуме историју и везу између прошлости и садашњости, ствара лични доживљај збивања, како оних историјских, о којима је читала, тако и стварних, које је имала прилике да види или о којима је имала прилике током свог боравка да слуша. На тај начин, долази до стварања мозаика сазнања. Током путовања, док се рвала са гомилом материјала, пронашла је ту вунену нит која је требало да је изведе из лавиринта. Очигледно је да је заволела Словене и Југославију. Стога је путопис

33 Игњачевић, 1994, стр. 113. 
посвећен њеним пријатељима у Југославији, који су сада већ сви мртви или поробљени. ${ }^{34}$ Може се закључити и да је идеализовала Словене и постала велики словенофил. Извесно негирање германске нације које је видљиво кроз путопис производ је духа времена у коме је писала, јер је било јасно са каквом претњом је свет био суочен. Била је свесна многих патњи и разарања кроз која је свет већ прошао након Великог рата, док се над њим надвијао нови облак претњи. Пре писања огромног штива као што је путопис Црно јаїне и сиви соко, у своме првенцу Поврайак райника ауторка

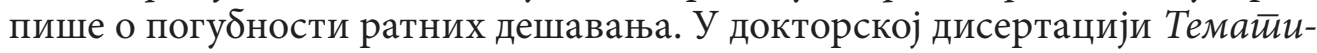

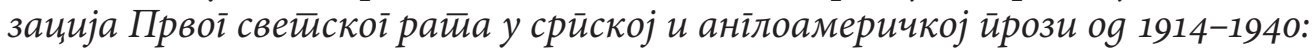
комйаратиивна анализа, Драган Бабић каже како се Вестова „не посвећује описивању рата и директних утицаја само на војнике, већ проговара о последицама рата на друштво као целину“"35. То је једно од првих дела које пише жена, а које говори о рату обрађујући пост-трауматски синдром. У односу на путопис који пише касније, прво ауторкино дело наликује путопису по ширини тема које обрађује и по слојевитости. Евидентно је да се истицала писањем које се није могло уклопити у појединачне жанрове. Из њених редова проговара и феминисткиња, али и борац за свеопшту правду, људска права, особа склона тумачењу историје, проналажењу смисла и психоанализи. Теме које обрађује многоструке су. Крећу се од односа „добра и зла, светлости и таме, живота и смрти, разобличавање неискрености и лицемерја ${ }^{\text {“36 }}$, те се све наведене теме преплићу у њеним делима. Кољевић примећује како је „под притиском нихилистичког искуства великог рата, и у времену нарастања фашистичке немани, [...] дошла у Југославију са стрепњом да је >воља за смрћуґ преплавила европску цивилизацију, и да се њој примакао крај“"з7. Мали народи о којима је писала постали су плен освајача. Међутим, њен лични доживљај тог времена, народа и догађаја, бива више пута изложен критици. На који год начин разумели критике, биле основане или не, остаје да се запитамо шта је то што је једну искусну новинарку и познату списатељицу са европског Запада, нагнало да разуме српски народ и истовремено остане верна својим ставовима. Као љубитељ византијске уметности, бива очарана културном баштином на Косову. Јасним ишчитавањем страница путописа недвосмислено се увиђа како себе издваја од других западних аутора. Разумевајући прошлост и садашњост, истрајна у преиспитивању токова историје и проналажењу њеног смисла, Вестова „много дубље разуме смисао косовске жртве ${ }^{\text {“38}^{8}}$. Могло би се рећи, да је мит са којим се сусрела за њу постао стваран.

34 Цитат Ребеке Вест на првој страни рукописа је: „Мојим пријатељима у Југославији, Који су сада сви мртви или поробљени."

35 Бабић, 2020, стр. 389.

36 Selić, 2017, стр. 838.

37 Koljević, 2000, стр. 4.

${ }^{38}$ Koljević, 2000, стр. 19. 


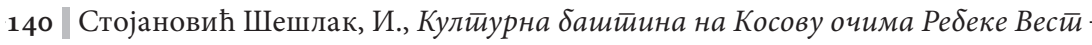

\section{Литература}

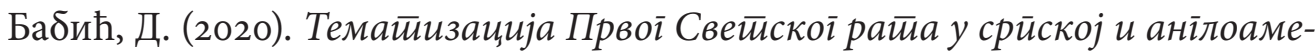
ричкој йрози оg 1914-1940: комйарайивна анализа. Докторска дисертација. Универзитет у Новом Саду, Филозофски факултет. Преузето 10.01.2021. ca: https://nardus.mpn.gov.rs/bitstream/handle/123456789/ 17185/Disertacija.pdf? sequence $=1$ \&isAllowed $=y$

Владика Николај (2003). Душа Србије. Ваљево: Глас цркве.

Vest, R. (2017). Crno jagnje i sivi soko: Putovanje kroz Jugoslaviju. Beograd: Vulkan Izdavaštvo.

Goldsvorti, V. (2005). Izmišljanje Ruritanije: Imperijalizam mašte. Beograd: Geopoetika.

Žunić, D. (2002). Nacionalizam i književnost - srpska književnost 1985-1995. Niš: Prosveta.

Игњачевић, С. (1994). Земла чуgа у изломленом ойлеgалу. Београд: DBR International Publishing, Библиотека Знамен.

Ковић, М. (2018). Косовски завет и национални идентитет Срба. Преузето 05.02.2019. ca: https://stanjestvari.com/2018/o2/12/kovic-kosovskizavet-nacionalni-identitet/

Ковић, М. (2020). Масарик и Срби: йолитичике иgеје. Београд: Српска политичка мисао.

Koljević, N. (2000). Jugoslavija Rebeke Vest. Y R. Vest, Crno jagnje i sivi soko (стр. 5-19). Beograd: BIGZ.

Кустурица, Е. (2018). Слово о академику Милораду Екмечићу. У Печай Милораgа Екмечића (стр. 5-11). Београд: Новости - Наш Печат.

Matić, M. (1993). Mit (politički). U Enciklopedija političke kulture (стр. 673-684). Beograd: Savremena administracija.

Миладиновић, А. (2019). Косовски мит у путописима о Краљевини Југославији. Саборности, XIII, 225-242.

Милеуснић, С. (1999). Светииюе Косова и Мейохије. Нови Сад: Православна реч.

Pavlović, A. (2019). Imaginarni Albanac: simbolika Kosova i figura Albanca u srpskoj kulturi. Beograd: Institut za filozofiju i društvenu teoriju.

Selić, A. (2017). Hronologija života i stvaralaštva Rebeke Vest. Y R. Vest, Crno jagnje i sivi soko (стр. 827-838). Beograd: Vulkan Izdavaštvo.

Станић, Р. (2002). Српска уметност од X до XVII века. У Кулиичрна ризнииза Србије: Србија, наслеђе, истиорија, кулитура (стр. 123-169). Београд: ИДЕА. 
Ivana Stojanović Šešlak

University of Belgrade, Faculty of Philology, Belgrade (PhD candidate)

\title{
Cultural heritage in Kosovo through the eyes of Rebecca West
}

\begin{abstract}
A large part of our public is familiar with the name of the British-Irish author A Rebecca West. Domestic journalism abounds with texts about the author due to her extremely positive writing about Serbs and Serbian culture. In the travelogue Black Lamb and the Gray Falcon, West expresses great admiration for our cultural heritage and understanding of our identity, which she identifies with the poem The Fall of the Serbian Empire. During her stay in Macedonia, she was introduced to Bishop Nikolaj, whom she considered one of the most extraordinary people she had ever met. In her travelogue, the author draws a comparison between the Battle of Kosovo in 1389 and England in 1939. In this paper, we will try to present her experience of monasteries in Kosovo, pointing to the fact that she considered herself different from other Western authors who, like herself, wrote about the Balkans.
\end{abstract}

Key words: Rebecca West, cultural heritage in Kosovo, Gračanica, Dečani.

Датум пријема чланка: 20. 05. 2021.

Датум прихватања чланка за објављивање: 25. 05. 2021. 